\title{
Hydrogen Technologies
}

\section{Hydrogen Analysis Group}

\section{Highlights}

The NREL Hydrogen Technologies and Systems Center and its Hydrogen Analysis Group are working to answer the key questions necessary to guide research and development of hydrogen technologies and infrastructure in support of U.S. Department of Energy program goals.

For example, the Hydrogen Analysis Group's " $\mathrm{H} 2 \mathrm{~A}$ " project analyzes hydrogen production costs using a standard calculation methodology and clearly specified assumptions; all of which were developed with input and acceptance from hydrogen stakeholders.

In addition, as part of the Controlled Hydrogen Fleet and Infrastructure Demonstration Validation Project, we are teaming with industry partners to collect and analyze extensive data on the operation of fuel cell vehicle fleets and fueling facilities.

\section{Hydrogen holds great promise for improved energy and transportation} systems of the future. This would, however, require dramatic changes to our energy and transportation infrastructures. How do we objectively determine the costs and benefits of these changes, the most cost-effective means of achieving them, and the top priority challenges to address?

The energy paradigm is shifting. The world is slowly moving from a fossil fuel-based economy to a new hydrogen-electric economy that will rely on sustainable renewable energy resources. This future energy economy has the potential to solve the major energy challenges that face the United States today: reducing dependence on petroleum imports, increasing our nation's energy security, and reducing air pollution and greenhouse gas emissions.

In the future energy economy, small, distributed power systems will play an increasing role in meeting the nation's need for sustainable electricity and hydrogen supplies. These distributed generators-which include fuel cells, natural-gas turbines, solar power, wind turbines, and others-will be located at or near the point of energy consumption and rely on regionally-available domestic resources. The Hydrogen Analysis Group at the National Renewable Energy Laboratory (NREL) is developing applications that will identify the most cost-effective pathways for bringing these resources on line.

There are a wide variety of technical challenges to achieving this transition to the new energy economy. The Hydrogen Analysis Group is using its analytical tools to chart the path for this massive market transformation.

Transitioning from traditional fossil fuels to renewable energy sources presents additional challenges. Do we have sufficient resources to support a new hydrogen-electric

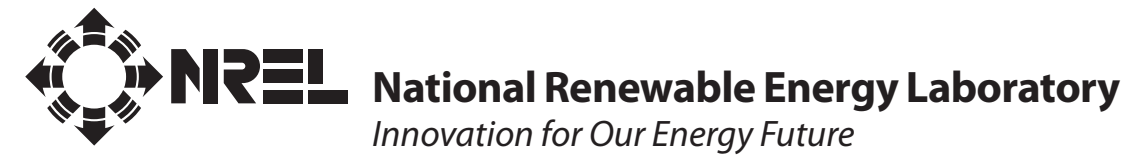


economy? Which locations have the best resources for distributed renewable energy systems? Do we have the tools to measure renewable resources accurately?

The Hydrogen Analysis Group is addressing these issues and helping to facilitate a smooth transition to the new energy future. In collaboration with industry, other institutes, and national laboratories, they are providing the nation with expertise in hydrogen and distributed power technologies and systems, and renewable resource characterization and measurement.

\section{Process and Systems Analysis}

Process and systems analysis provides direction, focus, and support for developing and commercializing hydrogen technologies.

Technoeconomic analyses are performed to determine the potential economic viability of a specific process, to direct research toward areas in which improvements will result in the largest cost reductions, and to design and optimize integrated systems.

Analytical models are developed to determine the most economical hydrogen delivery option for a given scenario. Geographical information systems (GIS) mapping of energy resources is used to identify opportunities for hydrogen production throughout the United States.
Life cycle assessments are performed to identify and evaluate the environmental impacts associated with a specific process. In these assessments, emissions, resource depletion, and energy consumption of all steps in the process are quantified-from the initial extraction of raw materials, through transportation and production, to the final disposal of products and by-products.

\section{Hydrogen Analysis Working Group (H2A)}

Coordinating analysis work being conducted on hydrogen and fuel cell systems is essential to ensure consistent analyses and a stronger understanding of the pathways to the hydrogen future. The Hydrogen Technologies and Systems Center Hydrogen Analysis Group works with the Department of Energy (DOE) to enable collaboration between analysis experts through the $\mathrm{H} 2 \mathrm{~A}$ project. $\mathrm{H} 2 \mathrm{~A}$, which stands for hydrogen analysis, was initiated in 2003 to leverage the talents and capabilities of a variety of analysis teams working on hydrogen systems and to establish a consistent set of financial parameters and analysis methods. For more information, visit the H2A Web site at www. hydrogen.energy.gov/h2a_analysis. html.

\section{Technology Validation}

To realize a future hydrogen-electric economy, fuel cell vehicles and a new hydrogen-based production, storage, and delivery infrastructure must be developed and demonstrated. The Hydrogen Technologies and Systems Center and its Hydrogen Analysis Group are working to integrate innovative research and development (R\&D) programs with creative deployment projects. The team is supporting DOE's Controlled Hydrogen Fleet and Infrastructure Demonstration Validation Project. This learning demonstration is a collaboration of auto and fuel cell manufacturers and energy companies focused on developing fuel cell vehicles and hydrogen infrastructure simultaneously. Testing R\&D advances in realworld operating conditions can help remove barriers to commercialization and identify future research needs.

To learn more about NREL's technology validation work, visit www.nrel.gov / hydrogen/proj_tech_validation.html.

\section{For More Information}

The work of the Hydrogen Analysis Group directly supports the goals of the DOE's Hydrogen, Fuel Cells \& Infrastructure Technologies Program $\mathrm{R} \& \mathrm{D}$ activities. To learn more about this work, visit www.eere.energy.gov / hydrogenandfuelcells.

\section{Contacts}

Hydrogen Technologies and Systems Center

Chris Gearhart, 303-275-3830,

chris.gearhart@nrel.gov

Hydrogen Analysis Group

Jennifer Kurtz, 303-275-4061,

jennifer.kurtz@nrel.gov

\section{National Renewable Energy Laboratory}

15013 Denver West Parkway, Colorado 80401

303-275-3000 • www.nrel.gov

NREL is a national laboratory of the U.S. Department of Energy

Office of Energy Efficiency and Renewable Energy

Operated by the Midwest Research Institute * Battelle

NREL/FS-5600-42834 • March 2008

Printed with a renewable-source ink on paper containing at least

$50 \%$ wastepaper, including 10\% post consumer waste. 